\title{
Students' preference for electronic and printed academic reading texts
}

\author{
Lok Raj Sharma \\ Tribhuvan University, Nepal
}

\begin{abstract}
Students' preference for the medium of academic reading texts has been diversified in the modern era. Some students' preference for attaining information and knowledge has been confined only to print media, some are found to be attracted to electronic media and some prefer to use both electronic and print media for their academic purposes. This article is based on the cross sectional survey carried out at nine campuses across Makawanpur district, Nepal in the Academic Year 2018-2019. The purpose of this study is to investigate the Bachelor of Business Studies students' preference regarding electronic and print media of reading texts. The researcher adopted simple random sampling to select 526 students from the population of 798 students. To collect data, the researcher used a questionnaire regarding the students' preference for electronic and print medium of the reading texts. Frequency and percent statistics of students who preferred print medium of reading texts; and the frequency and percent statistics of students who preferred electronic medium of reading show that more students in the research study preferred the print medium of reading texts versus the electronic medium. The chi-square test of independence Ç2 $(1)=0.631$, critical value $=3.841$ and $p>.05$ show that statistically, there was no significant association between gender and the preferred medium of the academic reading texts.
\end{abstract}

Keywords: Chi-Square Test, electronic medium, print medium, reading texts.

\section{Introduction}

Reading is one of the ways of gaining information and knowledge. It plays a key role in the process of learning. It is one way of transferring ideas from the writer to the reader through a written text that can be print or electronic. Without reading, an individual probably will not be able to get information of what is happening on in the world and cannot keep up with the development in his or her surroundings and expertise areas. Reading is one of the distinctive signs of a civilized society, where not only students, but also general people crave for reading and studying things. In the ancient time, people had to read print reading materials such as books, 
newspapers, magazines, notice etc., but nowadays, we have options that we can read print reading texts or electronic reading materials or both because of development of science and technology. In the modern era, both teachers and students can widen the horizon of their knowledge about anything through using print texts and electronic reading materials, but reading tendency of students, in general, seems to move from the print texts to the electronic reading materials in the developed countries. Students are still using print texts in developing countries, like Nepal, where modern facilities are unavailable, particularly in remote rural areas. Even several students dwelling in urban areas are deprived of having electronic reading materials because of poverty, ignorance and lack of the policy of the government. Foasberg (2014) asserts that there are several reasons that readers and students, in particular, may choose one reading format over another. Readers' personal preferences may come into play when they are selecting reading formats. Rainie, Zickuhr, Purcell, Madden and Brenner (2012) remark that there is some evidence that individuals do not limit themselves solely to either print or electronic media but often use both. In Worden and Collinson's study (2011), students' comments indicated that they preferred e-books for finding quotations, copying and pasting, while they preferred print for sustained reading.

The researcher carried out this study involving Bachelor of Business Studies (BBS) students of nine campuses situated in the Makawanpur district to investigate their preference for the electronic or print media of academic reading texts. The students involved in this research came from varied geographical vicinities such as rural areas, urban areas, and semiurban areas. The students belonged to diverse family backgrounds, fluctuating learning propensities and different financial status may represent all the students across Nepalese campuses.

This research study is significant because there is a lack of research on this topic in Nepal in general and in the Makawanpur district in particular. This research article explores which medium of academic reading text was preferred more and why the students preferred that medium.

\section{Objectives of the study}

The key objectives of the research study were:

To examine the Bachelor of Business Studies students' preference for the electronic and print medium of academic reading texts.

To explore the major reasons for preferring the medium of academic reading tests.

To investigate the association between gender and the medium of academic reading texts.

The null hypothesis of the study was:there is no statistically significant association between gender and the preferred medium of the reading texts. 


\section{Literature review}

\section{Reading as a process}

Reading is a complex process in which symbols and signs are decoded for constructing meaning. As a receptive process, different readers decode reading differently, and as a consequence, they create different meanings or understanding from the same text. In thisprocess, information from the text and the readers' knowledge act together to produce meaning.

Reading, which is a complex interaction between the text and the reader, is shaped by the reader's prior knowledge, experiences, attitude, and language community which is culturally and socially situated. The reading process requires continuous practice, development, and refinement. Cooper, Edna and Dorothy (1988) define comprehension as "a process of constructing meaning from clues in the text and information in the readers' background of experience" (p.27). Reading is normally an individual activity, although a person tends to read out loud for the benefit of other listeners. Reading aloud for one's own use, for better comprehension, is a form of intrapersonal communication.

\section{Digital reading material}

Digital media are encoded in machine readable formats. Digital media can be created, viewed, distributed, modified and preserved on digital electronics devices. The media can be pictures, sound, motion video, animation, and/or text items combined in a product whose purpose is to deliver information. Digital media include software, digital images, digital video, video game, web pages and websites, including social media, data and databases, digital audio, such as MP3 and electronic books. Digital media often contrasts with print media, such as print books, newspapers and magazines, and other traditional media, such as images, movies or audio tapes.In short, digital reading materials can be explained as reading materials that are presented in digital / electronic form using devices. Kindle, mobile phone, tablet, lap top and desk top are common media of the academic reading texts.

\section{Printed reading materials}

Print medium includes all types of magazines, newspapers, books, newsletters, banners, graphics, posters and other print artifacts. The flourishing of the new media with all its adjunct services seems to mark the beginning of the end of conventional reading. The term conventional means traditional and ordinary. In this study, conventional reading materials mean reading materials that are in the conventional form using the print media. Print media is one of the oldest and basic forms of communication. The contribution of print media in providing information and transfer of knowledge is remarkable. Even after the advent of electronic media, the print media has not lost its charm or relevance. In this study, print reading texts refer to the conventional reading materials that are provided for the readers using print paper such as print text books, newspapers, books, etc. 


\section{Previous research on reading materials}

Spencer (2006) carried out a study on the preferences of university students for their reading on-line course-related materials. Her results showed that many learners prefer the paper version of course materials and even those who prefer reading from screen indicated their desire to have the option for print version due to its portability, reliability, annotation, highlighting and ergonomic features. Another research on university students was done by Liu (2006) in order to investigate their perception, preferences and use of print or electronic resources. He concluded that digital libraries and traditional libraries have their unique advantages and limitations. Buzzetto-More, Sweat-Guy and Elobaid (2006) studied the awareness of university students about e-books. They found that, although university students were very comfortable about reading from the screen, they hardly had any interaction with e-books. In another study with university students in the UAE by Alghazo (2006), it was concluded that web-enhanced instruction is positively viewed by students and it seems to enrich the conventional faceto-face classroom environment.

Kazanci (2015) carried out the research by involving 792 randomly selected students from eight different departments of Faculty of Education at Çukurova University in Turkey. Her study showed that the majority of the students preferred traditional print paper instead of digital screen for their reading activities.
Davy (2007) found that e-textbooks had several good qualities over their traditional print copy counterparts. He found they were ubiquitous items, interactive, provided multi6 media, enabled printing on demand, thus saving paper, and could cater to individual learning styles. E-textbooks offer greater flexibility and accessibility than print copies, and e-textbooks proved increased visual appeal. Neither of these researchers cited any disadvantages of e-textbooks.

In an examination of college student's preferences, Rowlands, Nicholas, Jamali and Huntington (2007) discovered etextbooks to be up-to-date, space savers, accessible around the clock, convenient, and they perceived e-textbooks to make it easier to create copies of the text. However, contrary to these advantages, the students also believed that etextbooks were difficult to read, annotate, and bookmark a page/place in the book. Portability and flexibility in searching/browsing were advantages of e-textbooks, in addition to full-text searching and reference linking. The disadvantages were that the technology may still be somewhat in its infancy and there may also be a lack of awareness of the software/hardware that is available for e-textbooks. Rao (2001) found electronic reading texts to be convenient, less expensive than print copies, portable, and instantly available.

Shrimplin, Revelle, Hurst and Messner (2011) find four distinct groups of readers, all of whom approached print and electronic texts in different ways: Book Lovers, who preferred print; Technophiles, who preferred electronic 
formats; Pragmatists, who use whatever format best suits their needs at the time; and Printers, who print out electronic texts to read them. Chelin, Briddon, Williams, Redman, Sleat and Ince (2009) point out that students used e-books if they were easier to access or if the print edition was not available, rather than because of any preference for them. Caporn, Bryant, Foster and Ransley (2011) affirm that the younger students in their study, who were between the ages of eighteen and twenty-one, were more attracted to e-books than older students were. Broadhurst and Watson (2012) speculate that students will demand additional printing credits if many materials are made available electronically.

Shelburne (2009) mentions that faculty and students appreciated computerbased e-books for the speed and convenience with which they can be accessed, but many readers prefer to print out sections rather than rely on a computer and an Internet connection for access. Berg, Hoffmann and Dawson (2010) remark students doing a simple lookup task used more effective strategies to navigate the print encyclopedias than the electronic ones. Trakhman and Alexander (2017) verify their results demonstrated a clear preference for digital texts, and students typically predicted better comprehension when reading digitally. Jeong (2012) clarifies that higher quiz scores indicating better comprehension in print-based texts, while eye fatigue and strain reported by students was greater when reading e-texts. Singer and Alexander (2016) assert that although students could recall the main ideas regardless of the text type, they were better able to recall key points linked to the main idea and other relevant concepts when reading print.Dobler (2015), Falc (2013), Mizrachi (2015), and Singer and Alexander (2016) affirm that students may declare their preference for print-based texts over etexts, but they can also appreciate using a combination of the two. Jeong (2012) remarks students overall appear to prefer print books, but they are also satisfied with e-texts. Dobler (2015) points out that the reason for a preference for print-based texts is that students may feel more easily distracted when reading e-texts. Muir and Hawes (2013) consider that students perceive e-texts' page-topage navigation tools as poor and the speed of page loading as slow. Falc (2013) points out that students encounter various technical difficulties when learning with e-texts, leading to frustration. Baek and Monaghan (2013) highlight the importance of print text by stating that print-based texts are considered superior for studying large sections of text. On the contrary, for Muir and Hawes (2013), student preferences for e-texts are centred on searchability; and for Mizrachi (2015), cost and accessibility. Hsiao, Tang, and Lin (2015) enunciate that attitudes towards e-texts are affected by their (perceived) usefulness, ease of use, whether they were enjoyable and pleasant to use. Stone and Baker-Eveleth (2013) view that the continuation of using a certain medium of text depends on a student's resultant intention.

Stoop, Kreutzer and Kircz (2015) state that "enhancing the electronic text instead of just turning it into a copy of the printed version seems to have helped the 
students to score higher on the test". Myrberg and Wiberg (2015) articulate the apps for e-reading lack the ability to present essential spatial landmarks, they give poor feedback on your progress as you read, and make it difficult for you to plan your reading since they do not show how much is left of the chapter/ book in a direct and transparent way.

Yoram Eden and Eshet-Alkalai (2013) and Young (2014) pinpoint that speed and recall differences between media are insignificant. Rockinson-Szapkiw, Courduff, Carter, and Bennett (2013), Stoop, Kreutzer and Kircz (2013b); and Sun, Chich-Jen and Kai-Ping (2013) affirm that electronic documents that optimize hypertext and multimedia to engage students can lead to improved learning outcomes. Stoop, Kreutzer and Kircz (2013a) remark that many students prefer to print out academic documents. Qayyum and Williamson (2014) consider information from the printed page to be more trustworthy.

According to Herman (2014), Lam, Lamand and McNaught (2009), electronic resources have grown as a cost effective alternative to print resources, with a range of multi-borrower licensing and purchase packages available.

Daniel and Woody (2013), Durant and Horava (2015), Yoram Eden and EshetAlkalai, (2013), Herman (2014) and Young (2014)describe that many researchers who have explored the effect of format on reading and comprehension, ask whether electronic documents are an improvement on their print predecessors within education. Rockinson-Szapkiw et al. (2013) and Stoop et al. (2013b) write that electronic documents have the potential to provide an engaging, interactive learning environment via hyperlinks and multimedia. Rose (2011) and Stoop et al. (2013a) mention that The ability to easily markup paper documents may be one reason why students express a preference for print versions of lengthy academic texts.

Stoop et al (2013b) and RockinsonSzapkiw et al. (2013) assert that students liked the idea of utilizing electronic documents for interactive learning. Tuncer and Bahadir (2014), and Martin and Platt (2001) explain that many studies found that participants preferred to print out documents that contained complex information for reading. Jabr (2013) explicates that reading from the screen can be difficult to ascertain how far one is through a multi-page article, and difficult to contextualize the passages within the document.

Noyes and Garland (2003) and Stoop et al. (2013a) conclude that participants gain a better understanding of the content when reading from paper. Daniel and Woody (2013) and Qayyum and Williamson (2014) note the distractive nature of advertisements and pop-ups within electronic material. Stoop et al. (2013b) and Rockinson-Szapkiw et al. (2013) find that the interactive capabilities of electronic documents had the potential to actively engage students in learning. These results suggest that each medium may have a role to play in education, particularly as students become more accustomed to reading and editing electronic documents. 
Several factors play great roles in shaping the learners' preference for the medium of reading texts: familiarity with and comfort levels of the medium or platform (Baek and Monaghan 2013; Chen et al. 2014; Weisberg 2011), the cultural attitudes of learners (Kretzschmar et al. 2013), the subject matter (John 2014), the length of text (Abdullah and Gibb 2008; Baek and Monaghan 2013; Gibson and Gibb 2011; Muir and Hawes 2013) and whether the text needs to be understood thoroughly or merely skimmed and scanned (Buzzetto-More, Sweat-Guy and Elobaid 2007; Dilevko and Gottlieb 2002; Dundar and Akcayir 2012; Jamali, Nicholas, Rowlands 2009; and Spencer 2006).

These previous research studies reveal the students' mixed preferences for electronic and print media of reading texts. It is obvious that both electronic and print media of academic reading media retain some merits and some demerits.

\section{Methodology}

\section{Research design}

A cross-sectional survey design was used to carry out the study. The researcher collected the primary data from the questionnaire to investigate the Bachelor of Business Studies students' preference for electronic and print medium of academic reading texts.

\section{Population}

The population of the study consisted of 798 Bachelor of Business Studies first year students studying at nine campuses across the Makawanpur District of Nepal in the Academic Year of 2018-2019.

\section{Sampling design}

The researcher followed the simple random sampling design to select 526 students from the campuses according to the sample size determination calculator by maintaining 95\% confidence level and $2.5 \%$ margin of error.

\section{Sample size by gender}

The research study consisted of 270 boys and 256 girls studying at nine campuses. This means that the number of boys was a bit greater than that of the girls.

\section{Age groups of the students}

The highest number of students belonged to the 19-20 age group with 365 students, the second largest group was of $21-22$ age group with 132 students and the rest , 29 students were aged between 17- 22 years

\section{Religions of the students}

356 students belonged to Hinduism, 130 students belonged to Buddhism, 34 students belonged to Christianity and 6 students belonged to Muslim Religion. The highest number of the students in the study belonged to Hinduism.

\section{Variables in the study}

In this cross-sectional survey research design, the researcher took Sex, print and electronic media of reading texts as ma- 
jor variables

\section{Research tools and data gathering procedure}

The researcher prepared multiple choice question items regarding students' preference for reading medium. The questions were administered among the students after giving them instruction about the questionnaire and its purpose. Their responses were maintained as the primary data. The secondary source of data included books, journal articles, web-sites etc.

\section{Analysis and interpretation of data}

The data were analysed by using Statistical Package for Social Sciences
(SPSS) 20 version. The researcher designed a series of question items to measure the students' preference for media. As the data were nominal or categorical, the researcher used the frequency and percent statistics to examine which reading medium is preferred by more students. The chisquare test of independence was employed to assess the hypothesis test or to determine the association between gender and the preferred reading medium.

\section{Students' preference for medium and reasons for preference}

The researcher used frequency and percent calculation to scrutinize the students' preference for medium and reasons for preference.

Table 1: Students' preference for print and electronic medium of reading texts

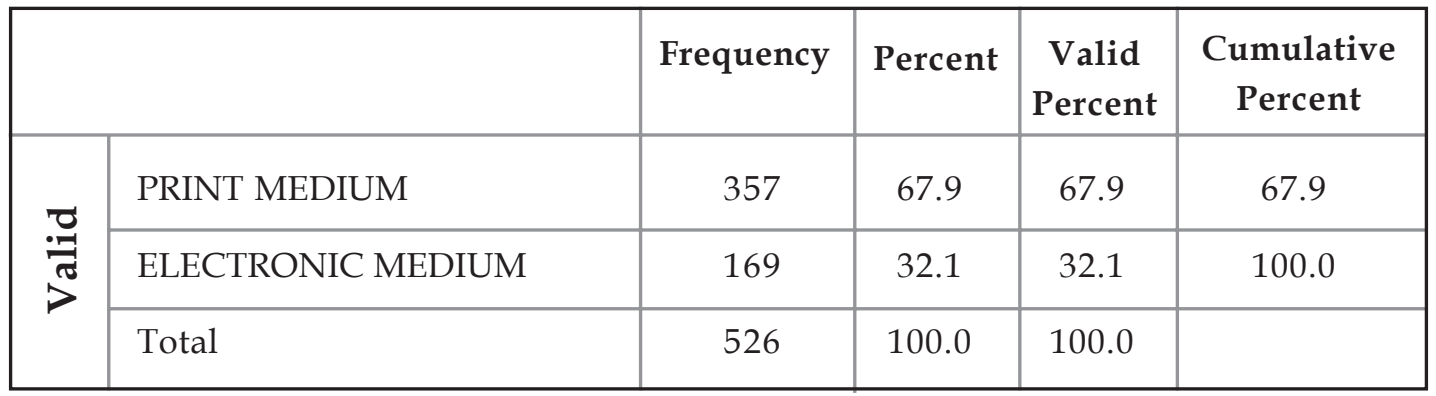

This table shows that most of the students preferred the print medium (67.9\%) to the electronic medium (32.1\%). 


\begin{tabular}{|c|c|c|c|c|c|}
\hline & Frequency & Percent & $\begin{array}{c}\text { Valid } \\
\text { Percent }\end{array}$ & $\begin{array}{l}\text { Cumulative } \\
\text { Percent }\end{array}$ \\
\hline \multirow{9}{*}{ 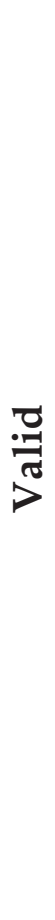 } & $\begin{array}{l}\text { Print: Easy to underline } \\
\text { main points }\end{array}$ & 135 & 25.7 & 25.7 & 25.7 \\
\hline & Print: Does not cause eye strain & 76 & 14.4 & 14.4 & 40.1 \\
\hline & $\begin{array}{l}\text { Print: Less distraction in the } \\
\text { course of reading }\end{array}$ & 82 & 15.6 & 15.6 & 55.7 \\
\hline & $\begin{array}{l}\text { Print: Cheaper than electronic } \\
\text { media }\end{array}$ & 64 & 12.2 & 12.2 & 67.9 \\
\hline & $\begin{array}{l}\text { Electronic: Interesting } \\
\text { to read }\end{array}$ & 58 & 11.0 & 11.0 & 78.9 \\
\hline & Electronic: Easy to read & 66 & 12.5 & 12.5 & 91.4 \\
\hline & $\begin{array}{l}\text { Electronic: Modern media } \\
\text { for reading }\end{array}$ & 31 & 5.9 & 5.9 & 97.3 \\
\hline & Electronic: No need to buy books & 14 & 2.7 & 2.7 & 100.0 \\
\hline & Total & 526 & 100.0 & 100.0 & \\
\hline
\end{tabular}

This table demonstrates that 135 (25.7\%) students preferred the print medium because they found the print medium easy to underline main points of the text. $76(14.4 \%)$ students preferred the print medium because they realized that the print medium did not cause eye strain; $82(15.6 \%)$ students found the print medium to cause less distraction in the course of reading; and $64(12.2 \%)$ preferred the print medium because of its low cost.

$58(11.0 \%)$ students preferred the electronic medium because they found the electronic medium interesting to read materials. 66 (12.5\%) students liked the electronic medium because they felt easy while reading on those medium. 31
(5.9\%) students they used the electronic medium because they were modern medium for reading; similarly, 14 (2.7\%) students used the electronic medium because they did not need to buy books.

\section{Chi-square $\left(x^{2}\right)$ test of indepen- dence}

The Chi-squared test of independence was used to determine the association between gender and preferred learning medium. 
Table 1: Gender of the student * preferred reading medium cross-tabulation

\begin{tabular}{|c|c|c|c|c|c|}
\hline & \multicolumn{2}{|c|}{ Media of Reading Texts } & \multirow[b]{2}{*}{ Total } \\
\hline & & & Print Media & $\begin{array}{c}\text { Electronic } \\
\text { Media }\end{array}$ & \\
\hline \multirow{8}{*}{ 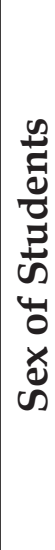 } & \multirow{5}{*}{$\frac{\stackrel{0}{J}}{\sum^{\frac{\pi}{2}}}$} & Count & 179 & 91 & 270 \\
\hline & & $\%$ within Sex of the Students & $66.3 \%$ & $33.7 \%$ & $100.0 \%$ \\
\hline & & $\%$ within Preferred Reading Medium & $50.1 \%$ & $53.8 \%$ & $51.3 \%$ \\
\hline & & $\%$ of Total & $34.0 \%$ & $17.3 \%$ & $51.3 \%$ \\
\hline & & Count & 178 & 78 & 256 \\
\hline & \multirow{3}{*}{ चี } & $\%$ within Sex of the Students & $69.5 \%$ & $30.5 \%$ & $100.0 \%$ \\
\hline & & $\%$ within Preferred Reading Medium & $49.9 \%$ & $46.2 \%$ & $48.7 \%$ \\
\hline & & $\%$ of Total & $33.8 \%$ & $14.8 \%$ & $48.7 \%$ \\
\hline \multirow{4}{*}{\multicolumn{2}{|c|}{ Total }} & Count & 357 & 169 & 526 \\
\hline & & $\%$ within Sex of the Students & $67.9 \%$ & $32.1 \%$ & $100.0 \%$ \\
\hline & & $\%$ within Preferred Reading Medium & $100.0 \%$ & $100.0 \%$ & $100.0 \%$ \\
\hline & & $\%$ of Total & $67.9 \%$ & $32.1 \%$ & $100.0 \%$ \\
\hline
\end{tabular}

This table shows that both male students and female students preferred to use print media of reading texts versus electronic media. Frequency and percent statistics show that $179(66.3 \%)$ and 91(33.7\%) male students preferred the print media of reading texts and electronic media respectively; similarly $178(69.5 \%)$ and $78(30.5 \%)$ female students preferred the print media of reading texts and electronic media of reading texts respectively. As a whole, $357(67.9 \%)$ students preferred print media of reading texts, whereas 169 $(32.1 \%)$ students preferred electronic media.
Table 2: Chi-Square test of indepe-ndence

\begin{tabular}{|l|c|c|c|}
\hline & Value & df & $\begin{array}{c}\text { Asymp. Sig. } \\
\text { (2-sided) }\end{array}$ \\
\hline $\begin{array}{l}\text { Pearson } \\
\text { Chi-Square }\end{array}$ & $.631^{\mathrm{a}}$ & 1 & .427 \\
\hline $\begin{array}{l}\text { Continuity } \\
\text { Correction }\end{array}$ & .491 & 1 & .483 \\
\hline $\begin{array}{l}\text { Likelihood } \\
\text { Ratio }\end{array}$ & .631 & 1 & .427 \\
\hline $\begin{array}{l}\text { Linear-by- } \\
\text { Linear } \\
\text { Association }\end{array}$ & .629 & 1 & .428 \\
\hline $\begin{array}{l}\text { N of Valid } \\
\text { Cases }\end{array}$ & 526 & & \\
\hline
\end{tabular}


a. 0 cells $(0.0 \%)$ have expected count less than 5 . The minimum expected count is 82.3 .

b. Computed only for a $2 \times 2$ table association between the two variables was found to be very weak (.035).

Figure 4: Students' preference for print vs electronic reading texts

"Pearson Chi-Square" value Ç2 $(1)=0.631$, which is smaller than the critical value 3.841 and $p=$ .427 , which was greater than .05 . This tells us that there was no statistically significant association between Gender and Preferred Learning Medium. It means both male students and female students almost equally preferred print media of reading texts versus electronic media. The result of the Chi-Square test of independence accepted the null hypothesis that there was no statistically significant association between gender and the preferred reading medium in the study.

\section{Table 3: Symmetric measures}

\begin{tabular}{|l|l|l|c|}
\hline \multicolumn{2}{|l|}{} & Value & $\begin{array}{c}\text { Approx. } \\
\text { Sig. }\end{array}$ \\
\hline $\begin{array}{l}\text { Nominal by } \\
\text { Nominal }\end{array}$ & Phi & .035 & .427 \\
\hline Cramer's V & .035 & .427 & \\
\hline N of Valid Cases & 526 & \\
\hline
\end{tabular}

a. Not assuming the null hypothesis.

b. Using the asymptotic standard error assuming the null hypothesis.

Phi and Cramer's V are both tests of the strength of association. Strength of
This figure also shows that there was no significant association between gender and the preferred reading medium. Gender could not determine the media of reading texts.

\section{Discussion and results}

The number and percent (357 or 67.9\%) of students who preferred print medium of reading texts and the number and percent $(169$ or $32.1 \%)$ of students who preferred electronic reading texts show that more students in the research study preferred print medium to electronic medium of reading texts. $66.3 \%$ of the boys and $69.5 \%$ of the girls preferred to use print medium of reading materials. The results indicate that the majority of students preferred print medium because it was easy to underline main points, such medium did not cause eye strain while reading, there was less distraction in the course of reading documents and low cost to buy print materials. 
The chi-square test of independence Ç2 $(1)=.631$, which was smaller than the critical value 3.841 and $p=.427$, which was greater than .05 show that there was no statistically significant association between gender and preferred medium of reading. Cramer's V- Test shows that the strength of association between gender and the preferred medium (.035) was poor.

\section{Conclusion}

Statistical analysis of the data demonstrates that more students in the research study preferred the print medium to the electronic medium of reading texts. The majority of students preferred to read print medium of texts because it was easy to underline main points. The chi-square test of independence shows that there was no statistically significant association between gender and the preferred medium of the reading texts. It can be concluded that most of the Nepalese students still prefer the print medium of reading texts for their academic purposes in spite of the wide use of diverse electronic media in reading and writing activities.

\section{Acknowledgements:}

I would like to thank Campus Chiefs and English teachers of the respective campuses of the Makawanpur district for their cordial cooperation and selfless interest in collecting the data required for my study. I am also thankful to the students for their genuine responses of the questionnaire.

\section{References}

Abdullah, N. \& Gibb, F. (2008). Students' attitudes towards e-books in a Scottish higher education institute: part 1'. Library Review, 57, 593-605.

Alghazo, I. M. ( 2006). Student attitudes toward web-enhanced instruction in an educational technology course. College Student Journal, 40(3), 4-9.

Baek, E. O. \& Monaghan, J. (2013). Journey to textbook affordability: an investigation of students' use of etextbooks at multiple campuses. International Review of Research in Open $\mathcal{E}$ Distance Learning, 14(1), 1-26.

Barthakur, R. (2013). Computer Vision Syndrome. Internet Journal of Medical Update, 8(2), 1-2.

Berg ,S. A., Hoffmann, K., \& Dawson, D. (2010). Not on the Same Page: Undergraduates' Information Retrieval in Electronic and Print Books . Journal of Academic Librarianship, 36(6), 521. doi:doi:10.1016/ j.acalib.2010.08.008.

Broadhurst ,D. \& Watson, J. (2012). E-book Readers for Full-Time MBA Students: An Investigation in Mancheste. Dominic Broadhurst and Janette WatsonJournal of Business $\mathcal{E}$ Finance Librarianship, 17(2), 177-184. doi:10.1080/08963568.2012.660735.

Buzzetto-More, N., Sweat-Guy, R. \& Elobaid, M. (2007). Reading in a digital age: e-books are students ready for this learning object? Interdisciplinary Journal of Knowledge \& Learning Objects, 3, 239-250.

Caporn ,S., Bryant, L., Foster ,K. \& Ransley ,E. (2011). Engaging Students with Ebooks in Further Education," in E-books in Libraries: A Practical Guide, ed. Kate Price and Virginia Havergal. London: Facet Publishing.

Chelin ,J. A., Briddon, J., Williams, E., Redman, J., Sleat, A. \& Ince, G. (2009). 
E-books Are Good If There Are No Copies Left': A Survey of E-book Usage at UWE Library Services. Library and Information Research, 4, 44-65. Retrieved August 24, 2019, from www.lirgjournal.org.uk/lir/ojs / index.php/lir/article/view/114

Chen, G., et al. (2014). A comparison of reading comprehension across paper, computer screens, and tablets: does tablet familiarity matter? Journal of Computers in Education, 1, 213-225.

Cooper, D. E. (1988). The what and how of reading instructions. Columbus: Merril Publishing Company.

Cull, B. (2011). Reading revolutios: Online digital text and implications for reading in academe. First Monday, 16(6). Retrieved August 21, 2019, from http:/ / pear.accc.uic.edu/ojs / index.php/fm/article/view/3340/ 2985

Daniel, D., \& Woody, W. D. (2013). Etextbooks at what cost? Performance and use of electronic v. print texts. Computers \& Education, 62, 18-23. doi:10.1016/j.compedu.2012.10.1016

Davy, T. (2007). E-textbooks: Opportunities, innovations, distractions, and dilemmas. Serials, 20(2), 98-102.

Dennis, A. R., et al. (2016). Effects of etextbook instructor annotations on learner performance'. Journal of Computing in Higher Education, 28, 221235.

Dilevko, J. \& Gottlieb, L. (2002). Print sources in an electronic age: a vital part of the research process for undergraduate students. Journal of Academic Librarianship, 28, 381-392.

Dobler, E. (2015). E-textbooks. Journal of Adolescent \& Adult Literacy, 58, 482491.

Dundar, H. \& Akcayir, M. (2012). Tablet vs. paper: the effect on learners' reading performance. International Electronic
Journal of Elementary Education, 4, 441450.

Durant, D. M., \& Horava, T. (2015). The future of reading and academic libraries. Portal: Libraries and the Academy, 5-27. Retrieved from https:/ / $\mathrm{m}$ u $\mathrm{s}$ e jhu.edu.ezproxy.lib.rmit.edu.au/ journals /

Falc, E. O. (2013). An assessment of college students' attitudes towards using an online e-textbook. Interdisciplinary Journal of E-Learning \& Learning Objects, 9, 1-12.

Foasberg, N. M. (2014, September). Student Reading Practices in Print and Electronic Media. College \& Research Libraries, 705-723. doi:doi:10.5860/ crl.75.5.705

Gibson, C. \& Gibb, F. (2011). An evaluation of second-generation ebook readers. Electronic Library, 29, 303-319.

Gilbert, J., \& Fister, B. (2015). The perceived impact of e-books on student reading practices: A local study. College and Research Libraries, 76(4), 469-489. doi:10.5860/crl.76.4.469

Herman, P. (2014, September 29). The hidden costs of e-books as university libraries. Times of San Diego, . Retrieved from http:/ / timesofsandiego.com/ opinion/2014/09/29/hidden-costs-ebooksuniversity-libraries/

Hsiao, C. H., Tang, K. Y. \& Lin, C. H. (2015). 'Exploring college students' intention to adopt e-textbooks: a modified technology acceptance model. Libri: International Journal of Libraries $\mathcal{E}$ Information Services, 65, 119-128.

Jabr, F. (2013). The reading brain in the digital age: The science of paper versus screens. Scientific American. Retrieved August 21, 2019, from www.scientificamerican.com/article/ reading-paper-screens/

Jamali, H. R., Nicholas, D. \& Rowlands, I. (2009). Scholarly e-books: the views of 
16,000 academics: results from the JISC National E-Book Observatory. Aslib Proceedings: New Information Perspectives, 61, 33-47.

Jeong, H. (2012). 'A comparison of the influence of electronic books and paper books on reading comprehension, eye fatigue, and perception. Electronic Library, 30, 390-408.

Kazanci, Z. (2015). University students' preferences of reading from a printed paper or a digital screen: A longitudinal study. International Journal of Culture and History, 1(1), 50-53. doi:10.18178/ ijch.2015.1.1.009

Kretzschmar, F, Pleimling, D, Hosemann, J., Füssel, S., Bornkessel-Schlesewsky, I. \& Schlesewsky, M. (2013). Subjective Impressions do not mirror online readingeEffort: Concurrent EEGeyetracking evidence from the reading of books and digital media. 8(2), e56178. doi:http://dx.doi.org/10.1371/

Lam, P., Lam, S., \& McNaught, C. (2009). Usability and usefulness of eBooks on PPCs: How students' opinions vary over time. Australasian Journal of Educational Technology, 25, 30-44. Retrieved from Retrieved from Proquest.

Liu, Z. (2006). Print vs. electronic resources: A study of user perceptions, preferences, and use. Information Processing \& Management, 42(2), 583592.

Martin, L., \& Platt, M. (2001). Printing and screen reading in the medical school curriculum: Guttenberg vs. the cathode ray tube. Behaviour \& Information Technology, 20, 143-148. . doi:10.1080/ 01449290110048043

Mizrachi, D. (2015). Undergraduates' academic reading format preferences and behaviors. The Journal of Academic Librarianship, 41, 301-311.

Muir, L. \& Hawes, G. (2013). The case for ebook literacy: undergraduate students' experience with e-books for course work. The Journal of Academic Librarianship, 39, 260-274.

Myrberg, C. \& Wiberg, N. (2015). Screen vs. paper: what is the difference for reading and learning? Insights, 28(2), 53.

Noyes, J. M., \& Garland, K. J. (2003). VDT versus paper-based text: Reply to Mayes, Sims and Koonce. International Journal of Industrial Ergonomics, 31, 411-423. . doi:10.1016//S01698141(03)00027-1

Qayyum, A., \& Williamson, K. (2014). The online information experiences of news-seeking young adults. Information Research, 20(2). Retrieved August 24, 2019, from http:// www.informationr.net/ir/19-2/ paper615. html\#.V2p9oaJXJh4

Rainie , L., Zickuhr, K., Purcell .K, Madden, M.\& Brenner, J. (2012, April 4). The Rise of E-Reading . Pew Research Center's Internet $\mathcal{E}$ American Life Project, 24-29. Retrieved August 24, 2019, from http:/ /libraries.pewinternet.org/201

Rao, S. (2001). Familiarization of electronic books. The Electronic Library, 19(4), 247256.

Rockinson-Szapkiw, A., Courduff, J., Carter, K., \& Bennett, D. (2013). Electronic versus traditional print textbooks: A comparison study on the influence of university students' learning. Computers and Education, 63, 259-266. doi:10/1016/j.compedu.2012

Rose, E. (2011). The phenomenology of onscreen reading: University students' lived experience of digitised text. British Journal of Educational Technology, 42, 515-526. . doi:10.1111/ j.1467- 8535.2009.01043.x

Rowlands, I., Nicholas, D., Jamali, H., \& Huntington, P. (2007). What do faculty and students really think about ebooks? Aslib Proceedings. New Information Perspectives, 59(6), 489-511. 
Shelburne, W. A. (2009). E-book Usage in an Academic Library: User Attitudes and Behaviors. Library Collections, Acquisitions \& Technical Services doi:10.1016/j. lcats.2009.04.002., 33(2), 55-59. doi: doi:10.1016/j. lcats.2009.04.002.

Shrimplin, A. K. , Revelle ,A., Hurst, S. \& Messner ,K. (2011). Contradictions and Consensus - Clusters of Opinions on Ebooks. College and Research Libraries, 72(2), 181-190. Retrieved August 24, 2019, from http://crl.acrl.org/ content/72/2/181.

Singer, L. M. \& Alexander, P. A. (2016). Reading across mediums: effects of reading digital and print texts on comprehension and calibration. The Journal of Experimental Education, 85(1), 155-172.

Spencer, C. (2006). 'Research on learners' preferences for reading from a printed text or from a computer screen'. Journal of Distance Education, 21, 33-50.

Stone, R. W. \& Baker-Eveleth, L. J. (2013). Students' intentions to purchase electronic textbooks. Journal of Computing in Higher Education, 25, 2747.

Stoop, J., Kreutzer, P. \& Kircz, J. G. (2013 a). Reading and Learning from Screens Versus Print: A Study in Changing Habits: Part 2 - Comparing Different Text Structures on Paper and on Screen. New Library World, 114(9/ 10), 371-383. . doi:http://dx.doi.org/10.1

Stoop, J., Kreutzer, P., \& Kircz, J. (2013 b). Reading and learning from screen versus print: A study in changing habits; Part 1. New Library World, 114, 284-300. . doi:10.1108/NLW-01-20130012

Sun, S. Y., Chich-Jen, S., \& Kai-Ping, H. (2013). A research on comprehension differences between print and screen reading. South African Journal of Economic and Management Sciences, 16,
87-101. Retrieved from http:// www.sajems.org/index.php/sajems/ art

Trakhman ,L. S.\& Alexander, P. (2017, March). Reading across mediums: Effects of reading digital and print texts on comprehension and calibration. The Journal of Experimental Education, 85(1), 155-172. doi:10.1080/ 00220973.2016.1143794

Tuncer, M., \& Bahadir, F. (2014). Effect of screen reading and reading from printed out material on student success and permanency in introduction to computer lesson. Turkish Online Journal of Educational Technology, 13, 44-49. Retrieved August 20, 2019, from http:/ / www.tojet.net/articles/v13i3/ 1335.pdf

Weisberg, M. (2011). Student attitudes and behaviors towards digital textbooks. Publishing Research Quarterly, 27, 188196.

Worden, A. \& Collinson, T. (2011). "Engaging Staff and Students with Ebooks in a University Setting. In A. W. Collinson, \& K. P. Haverga (Ed.), Ebooks in Libraries: A Practical Guide (pp. 237-251). London: Facet Publishing.

Yoram Eden, S., \& Eshet-Alkalai, Y. (2013). The effect of format on performance: Editing text in print versus digital formats. British Journal of Educational Technology, 44, 846-856. doi: 10.1111/ j.1467- 8535.2012.01332.x

Young, J. (2014). A study of print and computer-based reading to measure and compare rates of comprehension and retention. New Library World, 115, 376-393. . doi:10.1108/NLW-05-20140051 


\section{Appendix-I}

\section{QUESTIONNAIRE}

Article Topic: Assessing Students' Preference for Medium of Academic Reading Texts

\section{Level: BBS First Year Campus:}

Student ID:

Tick the most appropriate option

1. Which medium of reading texts do you prefer?
a. Print medium
b. Electronic medium

Hint: If your option is (a), move to the question number 2. If your option is (b), move to the question number 3.

2. Why do you prefer the print medium of reading texts?
a. The print medium is easy for the students to underline main points of the text.
b. The print medium does not cause eye strain while reading on it.
c. The print medium causes less distraction in the course of reading
d. The print medium is cheaper than the electronic medium to use.

3. Why do you prefer the electronic medium of reading texts?

a. The electronic medium is interesting to read.

b. The electronic medium makes the students easy to read.

c. The electronic medium is a modern medium for reading.

d. The students do no need to buy books while using the electronic medium.

Thank you very much for your genuine responses.

Contributor: Lok Raj Sharma is Associate Professor of English at Makawanpur Multiple Campus, Hetauda. He has completed M.A. and M.Ed. in English from Tribhuvan University, Nepal. He has published ten articles in different international journals of research. He is now doing research under grants of the University Grants Commission, Nepal. 